\title{
Insecticidal activity of crude extracts of three spices and commercial botanical pesticide on oriental fruit fly under laboratory conditions
}

\author{
Juliana Amaka Ugwu ${ }^{1 *}$ (D), Olajumoke Yemisi Alabi ${ }^{2}$ and Olawale Julius Aluko ${ }^{1}$
}

\begin{abstract}
Background: The uses of botanical pesticides in pest management are currently on remarkable increase due to their efficacy, biodegradability, environment-friendly, and availability. Ethanol extracts of three spices (Piper guineense, Aframomum melegueta, Zingiber officinale) and commercial botanical pesticide AzaSol (6\% azadirachtin) were assessed for contact toxicity, residual effects, and for their potential in soil application against pupariating larvae of oriental fruit fly (Bactrocera dorsalis) in the laboratory at ambient temperature of $27 \pm 2{ }^{\circ} \mathrm{C}$ and relative humidity of $75-80 \%$. The extracts and AzaSol were applied at 1:1.5 w/v concentration while cypermethrin was introduced as standard check and applied at $5 \mathrm{ml} /$ liter of water.
\end{abstract}

Results: All the treatments were very effective against $B$. dorsalis in contact toxicity and residual affects recording 89.4100\% larval mortality at $24 \mathrm{~h}$ post-application. Z. officinale and cypermethrin had similar contact and residual effects on B. dorsalis, both recording $100 \%$ larval mortality at $24 \mathrm{~h}$ post-exposure. Piper guineense showed higher residual effects than contact effects, while A. melegueta and AzaSol showed better contact effects than residual effects against $B$. dorsalis larvae. AzaSol was the most effective among the botanicals in reducing the adult emergence and in enhancing larval mortality (96.7\%) on treated soil followed by Piper guineense (83.3\%). The efficacy of AzaSol on the treated soil was comparable to cypermethrin. All the extracts were significantly more effective than control in enhancing pupariating larvae mortality and in reducing adult emergence on treated soil.

Conclusion: Ethanol extracts of $P$. guineense and A. melegueta were highly promising against $B$. dorsalis on treated soil and could be adopted in soil application targeting puparia under the tree canopies as part of integrated pest management of $B$. dorsalis in orchards.

Keywords: Bactrocera dorsalis, Pupariating larvae, Soil treatment, Plant extracts, Mortality

\section{Background}

Globally, Tephritid fruit flies (Diptera: Tephritidae) are among the most important insect pests of fruits and vegetable causing significant economic losses to farmers (Badii, Billah, Afreh-Nuamah, Obeng-Ofori, \& Nyarko, 2015). The oriental fruit fly, Bactrocera dorsalis (Hendel)

\footnotetext{
*Correspondence: dr.amaka2013@gmail.com

${ }^{1}$ Forestry Research Institute of Nigeria, P.M.B.5054, Jericho Hills, Ibadan, Oyo State, Nigeria

Full list of author information is available at the end of the article
}

(Diptera; Tephritidae) is one of the most important fruit fly species devastating fruit productions in sub-Saharan Africa region. Fruit production and exports in Africa is one of the agricultural sector that plays a vital role in the growth of local economy of the region, providing sources of livelihood for farmers, foreign exchange revenues, and job opportunities to many populace in the continent (Mengesha, Abate, Adamu, Zewde, \& Addis, 2019). Several fruits like mango, pawpaw, avocado, and citrus are grown in Africa for exports to foreign 
countries like the USA, Europe, and Middle East. The menace of fruit fly infestations in the region has hampered the production of exportable fruits in the region for the past decades since the arrival of $B$. dorsalis in the region. Bactrocera dorsalis is highly polyphagous and can infest and induce a substantial economic losses to a wide variety of fruit crops like mango, guava, citrus, mandarin, peach, and pawpaw (Ekesi, Maniania, Mohamed, \& Lux, 2005; Jin, Zeng, Lin, Lu, \& Liang, 2011; Stephens, Kriticos, \& Leriche, 2007). Bactrocera dorsalis causes losses to fruits through direct damage, fruit drops, and export restrictions due to quarantine regulations. Different management strategies for fruit fly species devastating crops has been developed in various parts of the world (Dias, Zotti, Montoya, Carvalho, \& Nava, 2018; Mau, Jang, \& Vargas, 2007; Vargas et al., 2001; Vargas, Mau, Jang, Faust, \& Wong, 2008). Some of these major control strategies include farm sanitation, foliage, and soil application of insecticides, bait spray, male annihilation techniques, biological control, release of sterilized flies, and parasitoids (Clark, Steck, \& Weems, 1996; Vargas et al., 2001, 2008; Vargas, Leblanc, Piñero, \& Hoffman, 2014). Application of insecticides on the soil under the host trees to kill fruit fly larvae and puparia is an important part of a fruit fly suppression and eradication program (California Department of Food and Agriculture, (CDFA), 1993; Roessler, 1989; Saul, Tsuda, \& Wong, 1983). However, the use of synthetic insecticides is detrimental due to its adverse effects on the environment and non-target organisms as well as toxic residues in fruits and associated restrictions in international trade on minimum residue levels (MRL) (El-Aw, Draz, Hashem, \& ElGendy, 2008). Screening plant botanicals for direct application to the soil, foliage spray, or incorporation into baits may disclose potential safer insecticide alternatives for fruit fly control. Plant extracts has been used widely and effectively in the management of several insect pests (Isman, 2006; Lengai, Muthomi, \& Mbega, 2020). Fruit fly species like $B$. zonata has been reported to show repellence effects and growth inhibition by the plant extracts from Kalmus (Acorus calamus), neem (Azadirachta indica) wild rue (Peganum harmala), and three other plant species (Akhtar, Jilani, Mahmood, Ashfaque, \& Iqbal, 2004). Acetone extracts of turmeric has been reported to show high repellent effects and growth inhibition of $B$. zonata (Siddiqi, Jilani, Rehman, \& Kanvil, 2006).

Extracts from $A$. indica has been reported to show anti-feeding effects, repellence, toxicity, and antioviposition effects on B. dorsalis and melon fly, B. cucurbitae (Shivendra \& Singh, 1998).

Aqueous extracts of A. indica, Piper guineense, Moringa oleifera, and Aframomum melegueta were found effective against oriental fruit fly larvae under laboratory condition (Ugwu \& Nwaokolo, 2020). This study therefore evaluated the efficacy of ethanol extracts of three spices (Piper guineense Schum and Thonn, Aframomum melegueta (Roskoe) K. Schum Zingiber officinale Roscoe, and Azasol (6\% azadirachtin)) against third instar larvae and pupariating larvae of $B$. dorsalis and their potential in reducing adult emergence on treated soil.

\section{Methods}

The study was conducted in the Biology Laboratory of the Federal College of Forestry Ibadan, Forestry Research Institute of Nigeria under ambient temperature of $27 \pm 2{ }^{\circ} \mathrm{C}$ and relative humidity of 70 to $80 \%$ and L12: D12 photoperiod. The extracts of spices evaluated include P. guineense, A. melegueta, Zingiber officinale, and Azasol (6\% azadirachtin), a commercial botanical from neem plant. Dried $A$. melegueta, $P$. guineense seeds, and fresh $Z$. officinale were purchased from a local market in Ibadan while Azasol (6\% azadirachtin) was procured from Arboget Company in Florida, USA

\section{Processing and extraction of plant materials}

Fresh Z. officinale roots were sliced into small chips and air dried for 2 weeks under ambient light conditions at fluctuating temperature of $27 \pm 2{ }^{\circ} \mathrm{C}, 75-80 \%$ relative humidity and L12: D12 photoperiod. All the dried plant materials ( $Z$. officinale roots, $P$. guineense seeds, and $A$. vhmelegueta) were ground into powder using an electric blender (Binatone blender/grinder BLG.450). The powdered plant materials were weighed out in $100 \mathrm{~g}$ each and extracted by Soxhlet method using $250 \mathrm{ml}$ of ethanol for minimum of $8 \mathrm{~h}$ according to Ofuya et al. (1992).

\section{Insect culture}

Populations of $B$. dorsalis were reared in the laboratory at ambient temperature of $25 \pm 2{ }^{\circ} \mathrm{C}$ and relative humidity of 70 to $80 \%$ on Irvingia gabonensis fruits. The infested fruits of Irvingia gabonensis were collected from the Irvingia plantation at Forestry Research Institute of Nigeria and were kept in a plastic cages in the laboratory and monitored for adult emergence. The emerged adults were paired in another cage for mating and oviposition. The rearing cages were supplied with fresh Irvingia fruits every 2 days after the first instar larvae emergence and the culture was maintained until the end of the experiment according to Ugwu (2020)

\section{Toxicity and residual bioassay}

Ethanol extracts of the three spices were evaluated for residual action by applying $1 \mathrm{ml}$ of each extracts on petri dishes lined with Whatman filter paper $(90 \mathrm{~mm})$. Petri dishes were left for $10 \mathrm{~min}$ to drain off before five third instar larvae of $B$. dorsalis were separately introduced into each petri dish. The contact toxicity of the extracts 
was assessed by applying $0.1 \mathrm{ml}$ of each extracts using $200 \mu \mathrm{l}$ micropipettes on the dorsal cavity of the insect. Ethanol extracts was applied at 1:1.5 w/v (75\%) concentration while liquid formulation of $6 \%$ azadirachtin (AzaSol) was prepared at $10 \mathrm{~g} / 100 \mathrm{ml}$ of water and applied at $1: 1.5 \mathrm{w} / \mathrm{v}(75 \%)$ concentration. Cypermethrin was introduced as a standard check and was applied at $5 \mathrm{ml} / \mathrm{liter}$ of water, while distilled water served as control for the entire test. All assays were replicated three times in a completely randomized design (CRD).

\section{Soil treatment with extracts and AzaSol}

Soil samples were collected from the experimental farm of Federal College Forestry, Ibadan, and $100 \mathrm{~g}$ were weighed into each plastic cage of $14 \mathrm{~cm} \times 9 \mathrm{~cm} \times 7 \mathrm{~cm}$. The soil was then treated with ethanol extracts and $6 \%$ azadirachtin (AzaSol) at $20 \mathrm{ml} / 100 \mathrm{~g}$ of soil. Cypermethrin was applied at $5 \mathrm{ml} / \mathrm{l}$ of water into $100 \mathrm{~g}$ of soil. Ten pupating $B$. dorsalis larvae were introduced into each cage on treated soil, covered with mosquito net, and observed for adult emergence. Each treatment was replicated three times in a CRD.

\section{Data collection and analysis}

Data on the mortality of $B$. dorsalis larvae were recorded at $20 \mathrm{~min}$ intervals for $24 \mathrm{~h}$ for both contact and residual bioassays, while adult emergence were recorded on the treated soil after 3 weeks (21 days). The pupating larvae mortality was inferred by calculating from the number of adult emergence after 21 days. Data collected were subjected to square root transformation before analysis of variance (ANOVA). Significant means were separated by Tukey's honestly significant difference (HSD) at 0.05 level of significance with ASSISTAT statistical software 7.6 beta.

\section{Results}

\section{Contact and residual effects of the botanicals on $B$.} dorsalis larvae

Plant botanicals evaluated showed contact toxicity on the third instar larvae of $B$. dorsalis under laboratory conditions. Larval mortality was observed from $60 \mathrm{~min}$ to $24 \mathrm{~h}$ post-treatments on all the botanicals (Table 1 ). Piper guineense and $Z$. officinale had similar larval mortalities with mean value of 0.67 at $60 \mathrm{~min}$ of postexposure. Aframomum melegueta recorded highest larval mortality with mean value of 2.33 at 100 min of postexposure, followed by $6 \%$ azadirachtin (1.33). The mortality action of $Z$. officinale was highest with mean value of 2.33 at $1440 \mathrm{~min}$ of post-exposure, and it was not significantly different $(p>0.05)$ from $6 \%$ azadirachtin (1.67). Synthetic insecticides (cypermethrin) were faster than all the treatments in killing all larvae at $100 \mathrm{~min}$ of post-exposure. All the botanicals significantly $(p<0.05)$
Table 1 Effect of contact toxicity of botanicals and synthetic chemical on B. dorsalis larvae

\begin{tabular}{llllllll}
\hline Time after application $(\mathbf{m i n})$ & & & & & \\
\hline Treatments & $\mathbf{2 0}$ & $\mathbf{4 0}$ & $\mathbf{6 0}$ & $\mathbf{8 0}$ & $\mathbf{1 0 0}$ & $\mathbf{1 2 0}$ & $\mathbf{1 4 4 0}$ \\
\hline P. guineense & 0.00 & $0.00 \mathrm{~b}$ & $0.67 \mathrm{a}$ & $1.33 \mathrm{a}$ & $0.67 \mathrm{~b}$ & $1.33 \mathrm{a}$ & $0.67 \mathrm{~b}$ \\
A. melegueta & 0.00 & $0.00 \mathrm{~b}$ & $0.00 \mathrm{~b}$ & $0.67 \mathrm{~b}$ & $2.33 \mathrm{a}$ & $1.33 \mathrm{a}$ & $0.67 \mathrm{~b}$ \\
Z. officinale & 0.00 & $0.00 \mathrm{~b}$ & $0.67 \mathrm{a}$ & $0.67 \mathrm{~b}$ & $1.00 \mathrm{ab}$ & $0.33 \mathrm{~b}$ & $2.33 \mathrm{a}$ \\
6\% azadiractin & 0.00 & $0.00 \mathrm{~b}$ & $0.33 \mathrm{~b}$ & $1.00 \mathrm{a}$ & $1.33 \mathrm{a}$ & $0.67 \mathrm{a}$ & $1.67 \mathrm{a}$ \\
Cypermethrin & 0.00 & $2.67 \mathrm{a}$ & $0.67 \mathrm{a}$ & $0.33 \mathrm{~b}$ & $1.33 \mathrm{a}$ & $0.00 \mathrm{~b}$ & $0.00 \mathrm{~b}$ \\
Control & 0.00 & $0.00 \mathrm{~b}$ & $0.00 \mathrm{~b}$ & $0.00 \mathrm{~b}$ & $0.00 \mathrm{~b}$ & $0.00 \mathrm{~b}$ & $0.00 \mathrm{~b}$
\end{tabular}

Means with the same letter within the same column do not differ statistically by Tukey's honestly significant difference (HSD)

caused larval mortality compared with the control where none of the larvae died.

The residual effects of the botanical followed a similar pattern with their contact toxicity. All the plant botanicals recorded larval mortality from $60 \mathrm{~min}$ postexposure (Table 2). Aframomum melegueta recorded highest larval mortality among the extracts with mean value of 0.67 at 60 min post-exposure. Piper guineense and $6 \%$ azadirachtin had equal larval mortality at $80 \mathrm{~min}$ post-exposure with mean value of 1.69 . The residual effects on the larvae continued until $24 \mathrm{~h}$ post-exposure. Cypermethrin commenced residual action on larvae from $40 \mathrm{~min}$ and gave $100 \%$ mortality at $120 \mathrm{~min}$ of post-exposure, while no mortality was recorded in the control throughout the period of observation.

\section{Comparison of contact toxicity and residual effects of treatments on mean percentage mortality of Bactrocera dorsalis larvae at $1440 \mathrm{~min}$ post-exposure}

Contact toxicity and residual effect of treatments were compared in Fig. 1. All the treatments proved very effective against $B$. dorsalis for both contact toxicity and residual effects at $24 \mathrm{~h}$ post-application (Fig. 1). Zingiber officinale had similar contact and residual effects with cypermethrin; both caused $100 \%$ larval mortality at $24 \mathrm{~h}$ post-exposure. Piper guineense slightly had higher

Table 2 The residual effects of the botanicals and synthetic chemical on $B$. dorsalis larvae

\begin{tabular}{llllllll}
\hline \multicolumn{7}{l}{ Time after application } & $(\mathbf{m i n})$ \\
\hline Treatments & $\mathbf{2 0}$ & $\mathbf{4 0}$ & $\mathbf{6 0}$ & $\mathbf{8 0}$ & $\mathbf{1 0 0}$ & $\mathbf{1 2 0}$ & $\mathbf{1 4 4 0}$ \\
\hline P. guineense & 0.00 & $0.00 \mathrm{~b}$ & $0.33 \mathrm{~b}$ & $1.67 \mathrm{a}$ & $1.33 \mathrm{~b}$ & $0.67 \mathrm{~b}$ & $1.00 \mathrm{~b}$ \\
A. melegueta & 0.00 & $0.00 \mathrm{~b}$ & $0.67 \mathrm{a}$ & $0.67 \mathrm{~b}$ & $0.67 \mathrm{~b}$ & $1.33 \mathrm{a}$ & $1.33 \mathrm{~b}$ \\
Z. officinale & 0.00 & $0.00 \mathrm{~b}$ & $0.33 \mathrm{~b}$ & $0.00 \mathrm{c}$ & $1.67 \mathrm{a}$ & 0.67 & $2.33 \mathrm{a}$ \\
6\% azadirachtin & 0.00 & $0.00 \mathrm{~b}$ & $0.33 \mathrm{~b}$ & $1.67 \mathrm{a}$ & $0.67 \mathrm{~b}$ & $1.67 \mathrm{a}$ & $1.00 \mathrm{~b}$ \\
Cypermethrin & 0.00 & $0.67 \mathrm{a}$ & $0.00 \mathrm{~b}$ & $1.00 \mathrm{~b}$ & $2.33 \mathrm{a}$ & $1.00 \mathrm{ab}$ & $0.00 \mathrm{c}$ \\
Control & 0.00 & $0.00 \mathrm{~b}$ & $0.00 \mathrm{~b}$ & $0.00 \mathrm{c}$ & $0.00 \mathrm{c}$ & $0.00 \mathrm{c}$ & $0.00 \mathrm{c}$
\end{tabular}

Means with the same letter within the same column do not differ statistically $(p<0.05)$ by Tukey's honestly significant difference (HSD) 


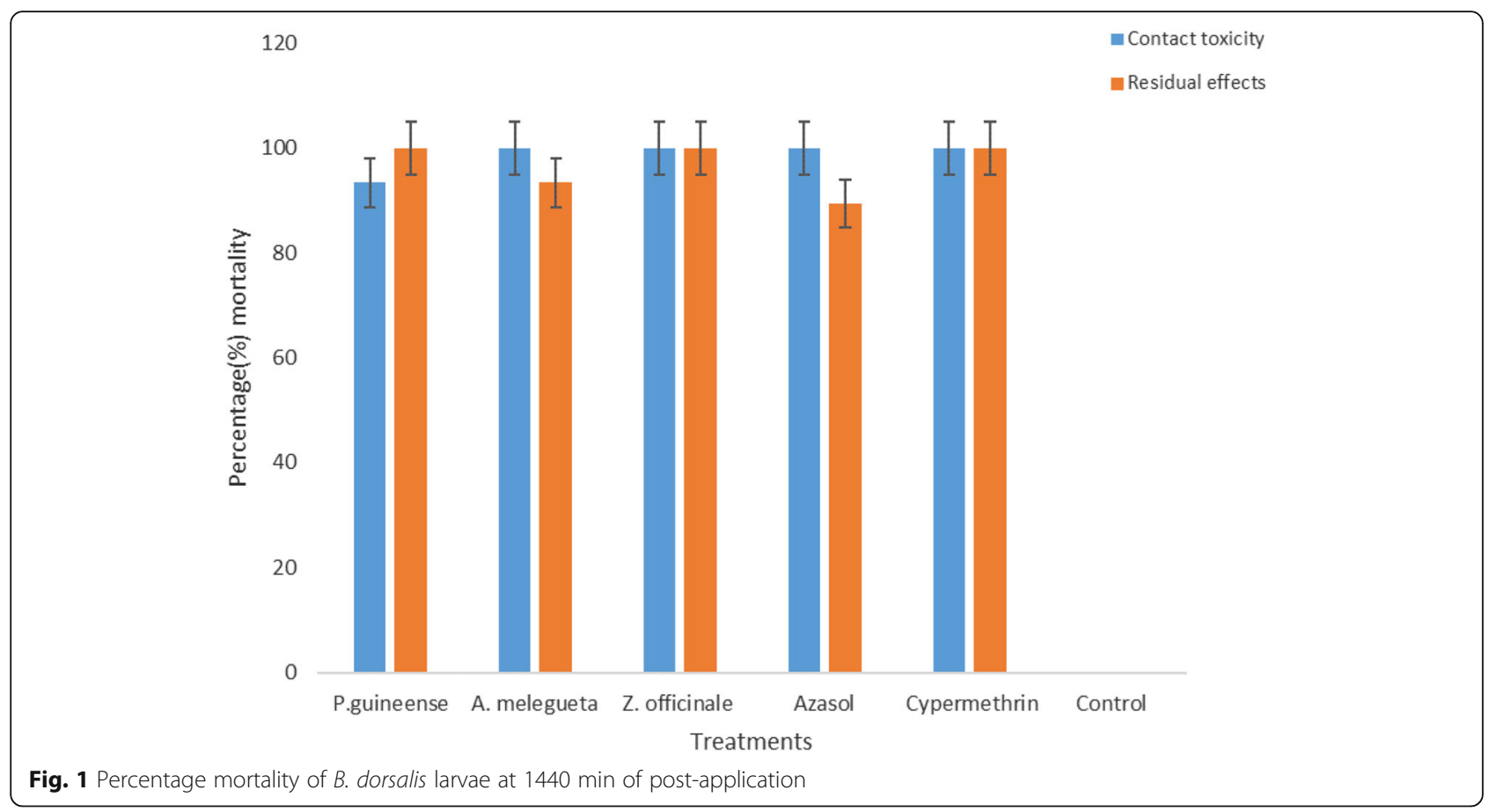

residual effects on $B$. dorsalis larvae than contact effects with $100 \%$ and $93.4 \%$ for residual and contact toxicity, respectively. Aframomum melegueta showed higher contact toxicity than residual effects recording 100 and 93.4\% mortality, respectively. AzaSol (6\% azadirachtin) had better contact effects than residual effects with 100 and $89.4 \%$, respectively compared with $P$. guineense.

\section{Effect of soil application of the botanicals on mortality and adult emergence of $B$. dorsalis}

The results showed that all the extracts were effective in reducing emergence of $B$. dorsalis adults on treated soil (Table 3). AzaSol (6\% azadirachtin) was the most effective among the botanicals in reducing the adult emergence and in enhancing larval mortality on treated soil. It caused $96.7 \%$ mortality of pupariating larvae followed by Piper guineense (83.3\%). The effect of AzaSol on B. dorsalis on treated soil was comparable with

Table 3 Effect of soil application of botanicals on mortality and adult emergence of $B$. dorsalis

\begin{tabular}{lll}
\hline Treatment & Mortality (\%) & Adult emergence (\%) \\
\hline P. guineense & $83.3 \mathrm{ab}$ & $16.7 \mathrm{~cd}$ \\
A. melegueta & $73.3 \mathrm{bc}$ & $26.7 \mathrm{bc}$ \\
Z. officinale & $56.7 \mathrm{c}$ & $43.3 \mathrm{~b}$ \\
6\% azadirachtin (Azaso)) & $96.7 \mathrm{a}$ & $3.3 \mathrm{dd}$ \\
Cypermethrin & $100.0 \mathrm{a}$ & $0.0 \mathrm{~d}$ \\
Control & $20.0 \mathrm{~d}$ & $80.0 \mathrm{a}$ \\
\hline
\end{tabular}

Mean values with the same letter within the column do not differ statistically $(p<0.05)$ by Tukey's honestly significant difference (HSD) cypermethrin (100.0\%). Aframomum melegueta caused above $70 \%$ larval mortality on treated soil. Zingiber officinale was least among the botanicals in causing pupariating larvae mortality (56.7\%). All the extracts were significantly more effective than control in causing pupariating larval mortality of $B$. dorsalis. Adult emergence was higher on untreated soil (control) with about $80 \%$, followed by soil treated with $Z$. officinale (43.3\%), A. melegueta (26.7\%), and P. guineense (16.7\%) while soil treated synthetic insecticide (cypermethrin) recorded no emergence of adult $B$. dorsalis. The higher the mortality, the lower the emergence.

\section{Discussion}

All the botanicals evaluated recorded high level of Bactrocera dorsalis larval mortality at both contact and residual effect at $24 \mathrm{~h}$ of exposure. The study has demonstrated the potential of the tested plant extracts to decimate populations of $B$. dorsalis larvae. This results support several reports from previous studies on the potential of plant botanicals in the management of fruit fly infestations. Akhtar et al. (2004) reported that extracts from Acorus calamus Linn, Azadirachta indica A. Juss, Curcuma longa L, Peganum harmala L, Saussurea lappa (Decne)Sch.Bip., and Valeriana jatamansi Jones inhibited the growth of Bactrocera zonata in Pakistan. Similarly, Jaleel et al. (2020) reported that Piper nigrum has been very effective in repelling $B$. correcta and $B$. dorsalis. Furthermore, aqueous extracts of $A$. indica, $P$. guineense, $M$. oleifera, and A. melegueta caused contact and residual toxicity against $B$. dorsalis at 
varied rates under laboratory conditions (Ugwu \& Nwaokolo, 2020). The insecticidal efficiency of P. guineense is attributed to Piperine the active ingredient in P. guineense (Scott et al., 2004). A. melegueta has been reported to possess several biological activities like antiinflammatory, antioxidant and anti-tumor effects, and anti-microbial activity (Chung, Jung, Surh, Lee, \& Park, 2001; Oloke, Kolawole, \& Erhun, 1998; Tjendraputra, Tran, Liu-Brennan, Roufogalis, \& Duke, 2001). Similarly, Ukeh, Birkett, Pickett, Bowman, and Luntz (2009) reported that $A$. melegueta and $Z$. officinale extracts exhibited repellent effect towards adult $S$. zeamais both in the absence and the presence of maize, Zea mays, grains. The biological activities of $A$. melegueta is attributed to three major compounds; (S)-2-heptanol, (S)-2-heptyl acetate, and ( $R$ )-linalool (Ukeh et al., 2009). Siddiqi et al. (2006) also reported that petroleum ether, acetone, and ethanol extracts of turmeric plant were effective in repelling and inhibiting growth of $B$. zonata. Several past studies have been documented on the potential of botanicals in the control of many insect pests of different crops both in the field and storage. Powders of $Z$. officinale, $A$. indica, A. melegueta, and other local plant materials have been found promising in protecting Cajanus cajan and Vigna unguiculata grains against Callosobruchus maculatus infestation in storage (Ekeh, Onah, Atama, Ivoke, \& Eyo, 2013). Similarly, Idoko and Adesina (2012) reported that $P$. guineense powder has contact effects on $C$. maculatus which resulted in adult mortality and inhibition of female oviposition. The residual and contact effects of $Z$. officinale on $B$. dorsalis were comparable to cypermethrin. These results corroborate the findings by Addo (2017) who reported that aqueous extracts of $Z$. officinale were effective against major pests of cabbage (Brassicae oleracea var. capitata). Giriraju and Yunus (2013) reported that 10\% ethanolic extracts of Z. officinale possess antimicrobial potential against pathogens. The antimicrobial and other several biological activities $\mathrm{Z}$. officinale are attributed to gingerol and paradol, shogaols, and zingerone (Rahmani, Al Shabrmi, \& Aly, 2014). Several studies have shown that plant botanicals were more effective than synthetic insecticides against various insect pests of crops both in the field and storage. Basedow, Obiewatsch, Bernal Vega, Kollmann, and Nicol (2002) reported that A. indicabased products were more efficacious than synthetic insecticides against aphids and white flies in the field. Similarly, Ugwu, Ojo, Aderolu, and Aderemi (2014) reported that $A$. indica seed extracts showed higher efficacy than Cypermethrin against leaf roller Sylepta derogata on okra in the field. In this study, Azasol (6\% azadirachtin) was very effective in reducing adult emergence of $B$. dorsalis on treated soil. The results supports the findings by Khan, Hossain, and Islam (2007) who reported that high doses of Azadirachtin, an active ingredient of $A$. indica, were found very effective in reducing the oviposition rates of oriental fruit flies on the melon plants. The efficacy of neem-based product is attributed to their molecular component which comprises complex mixture of molecules with hydrocarbons, phenolic compounds, terpenoids, alkaloids, and glycosides (Hossain, Al-Toubi, Weli, Al-Riyami, and Al-Sabahi (2013). According to Mordue-Luntz and Nisbet (2000), neem molecules act on the life cycle of insects in various phases making it difficult for pests to resist the physiological effects of neem-based extracts. Solangi, Sultana, Wagan, and Ahmed (2011) reported that extracts of neem oil, neem seed powder solution, eucalyptus leaf, and tobacco leaf showed repellent effects against Bactrocera zonata. Similarly, Rehman, Jilani, Khan, Masih, and Kanvil (2009) reported that $A$. indica was very effective in reducing the oviposition rate of $B$. zonata, $B$. dorsalis, and B. olae. According to Isman (2000) and Cetin, Erler, and Yanikoglu (2004), plant extracts and their oils possess ovicidal, larvicidal, and repellent properties against various insect species. The most vital constituent of several plant extracts or their essential oils are monoterpenoids which possess fumigant properties making them a good element in pest management program (Ahn, Lee, Lee, \& Kim, 1998; Al Qahtani, Al-Dhafar, \& Rady, 2012; Regnault-Roger \& Hamrouni, 1995)

The use of botanicals in pest management has shown great promise as alternatives to chemical insecticides to reduce pesticide load in the environment (Radha \& Susheela, 2014).

\section{Conclusion}

The current study has proved that ethanol extracts of Zingiber officinale, Piper guineense Aframomum melegueta, and Azasol have strong insecticidal activity. AzaSol was most effective in reducing adult emergence of $B$. dorsalis on treated soil. Plant botanicals have proven to be environment-friendly and effective in pest management in several forms of application either as foliar spray or soil application. The commercial botanical (AzaSol) has proved to be more effective than ethanol extracts of the tested spices in soil application. Thus, further efforts should be made to develop these plant extracts in readymade formulations to enhance their efficacy for several application methods.

\section{Abbreviations \\ FCF: Federal College of Forestry; FRIN: Forestry Research Institute of Nigeria; GMT: Greenwich Meridian Time}

\section{Acknowledgements}

The authors are grateful to the field assistant who helped in maintaining the field during the research activities. 


\section{Authors' contributions}

JAU conceptualized, designed, implemented the research, and drafted the manuscript. OJA analyzed of the results of the research while OYA edited the manuscript draft. All authors read and approved the final manuscript.

\section{Funding}

This research did not receive any specific grant from funding agencies in the public, commercial, or not-for-profit sectors

\section{Availability of data and materials}

All data generated or analyzed during this study are included in this published article.

\section{Declarations}

\section{Ethics approval and consent to participate}

Not applicable.

\section{Consent for publication}

Not applicable.

\section{Competing interests}

The authors declare that they have no competing interests.

\section{Author details}

${ }^{1}$ Forestry Research Institute of Nigeria, P.M.B.5054, Jericho Hills, Ibadan, Oyo State, Nigeria. ${ }^{2}$ Department of Crop Protection \& Environmental Biology, University of Ibadan, Ibadan, Nigeria.

\section{Received: 11 January 2021 Accepted: 5 May 2021}

Published online: 17 May 2021

\section{References}

Addo, A. (2017). The effect of aqueous ginger (Zingiber officinale) extracts on the management of major pests of cabbage (Brassicae oleracea var. capitata). In An MS.c Thesis submitted to the Department of Theoretical and Applied Biology, College of Science, Kwame Nkrumah University of Science and Technology, Kumasi, (pp. 41-58) Goggle Scholar.

Ahn, Y. J., Lee, S. B., Lee, H. S., \& Kim, G. H. (1998). Insecticidal and acaricidal activity of caravacrol and b-thujaplicine derived from Thujopsis dolabrata var. hondai sawdust. Journal of Chemical Ecology, 24, 81-90 Cross ref. Goggle scholar.

Akhtar, N., Jilani, G., Mahmood, R., Ashfaque, M., \& Iqbal, J. (2004). Effects of plant derivatives on settling response and fecundity of peach fruit fly Bactrocera zonata (Saunders). Sarhad Journal of Agriculture, 20, 269-274 Goggle Scholar.

Al Qahtani, A. M., Al-Dhafar, Z. M., \& Rady, M. H. (2012). Insecticidal and biochemical effect of some dried plants against Oryzaephilus surinamensis (Coleoptera-Silvanidae). The Journal of Basic \& Applied Zoology, 65(1), 88-93. https://doi.org/10.1016/j.jobaz.2012.10.008.

Badii, K. B., Billah, M. K., Afreh-Nuamah, K., Obeng-Ofori, D., \& Nyarko, G. (2015). Review of the pest status, economic impact and management of fruitinfesting flies (Diptera: Tephritidae) in Africa. African Journal of Agricultural Research, 10(12), 1488-1498. https://doi.org/10.5897/AJAR2014.9278.

Basedow, T., Obiewatsch, H. R., Bernal Vega, J. A., Kollmann, S., \& Nicol, C. M. Y. (2002). Control of aphaid and white flies (Homoptera; Aphididae and Aleyrodidae) with different neem preparations in laboratory, greenhouse and field: effects and limitations. Journal of Plant Diseases Protection, 109, 612-623 Goggle scholar.

California Department of Food and Agriculture, (CDFA) (1993). Final programmatic environmental impact report: the exotic fruit fly eradication program utilizing male annihilation and allied methods. State Clearinghouse No. 90021212, Sacramento, CA

Cetin, H., Erler, F., \& Yanikoglu, A. (2004). Larvicidal activity of a botanical natural product, AkseBio2, against Culex pipiens. Fitoterapia, 75, 724-728 Cross ref. Google scholar.

Chung, W.-Y., Jung, Y.-J., Surh, Y.-J., Lee, S.-S., \& Park, K.-K. (2001). Antioxidative and antitumour promoting effects of (6)-paradol and its homologs. Mutation Research, 496, 199-206 Google scholar.

Clark, R. A., Steck, G. J., \& Weems, H. V. (1996). Detection, quarantine, and eradication of exoticfruit flies in Florida. In D. Rosen, F. D. Bennett, \& J. L.
Capinera (Eds.), Pest Management in the Subtropics Integrated Pest Management -A Florida Perspective, (pp. 29-54). Intercept Goggle scholar.

Dias, N. P., Zotti, M. J., Montoya, P., Carvalho, I. V., \& Nava, D. E. (2018). Fruit fly management research: A systematic review of monitoring and control tactics in the world. Crop Protection, 112, 187-200 https://www.researchgate.net/ publication/325951012.

Ekeh, F. N., Onah, I. E., Atama, C. I., Ivoke, N., \& Eyo, J. E. (2013). Effectiveness of botanical powders against Callosobruchus maculatus (Coleoptera: Bruchidae) in some stored leguminous grains under laboratory conditions. African Journal of Biotechnology, 12(12), 1384-1391. https://doi.org/10.5897/AJB12.2 784 Goggle scholar.

Ekesi, S., Maniania, N. K., Mohamed, S. A., \& Lux, S. A. (2005). Effect of soil application of different formulations of Metarhizium anisopliae on African tephritid fruit flies and their associated endoparasitoids. Biological Control, 35(1), 83-91. https://doi.org/10.1016/j.biocontrol.2005.06.010.

El-Aw, M. A. M., Draz, K. A. A., Hashem, A. G., \& El-Gendy, I. R. (2008). Mortality comparison among Spinosad-, Actara-, Malathion-, and Methomyl-containing baits against peach fruit fly, Bactrocera zonata (Saunders) (Diptera: Tephritidae) under laboratory conditions. Journal of Applied Science and Research, 4, 216-223 Goggle scholar.

Giriraju, A., \& Yunus, G. Y. (2013). Assessment of antimicrobial potential of 10\% ginger extract against Streptococcus mutans, Candida albicans, and Enterococcus faecalis: an in vitro study. Indian Journal of Dental Research, 24, 397-400.

Hossain, M. A., Al-Toubi, W. A. S., Weli, A. M., Al-Riyami, Q. A., \& Al-Sabahi, J. N. (2013). Identification and characterization of chemical compounds in different crude extracts from leaves of Omani neem. Journal of Taibah. University of Science, 7, 181-188 Goggle scholar.

Idoko, J. E., \& Adesina, J. M. (2012). Evaluation of the powder of Piper guineense and pirimiphos-Methly $\mathrm{F}$ for the control of cowpea beetle Callosobruchus maculatus (F.). Journal of Agricultural Technology, 8(4), 1365-1374 https:// www.researchgate.net/publication/282866424.

Isman, M. B. (2000). Plant essential oils for pest and disease management. Crop Protection, 19(8-10), 603-608. https:/doi.org/10.1016/50261-2194(00)00079-X Goggle scholar.

Isman, M. B. (2006). Botanical insecticides, deterrents, and repellents in modern agriculture and an increasingly regulated world. Annual Review of Entomology, 51, 45-66 Goggle scholar.

Jaleel, W., Wang, D., Lei, Y., Qi, G., Chen, T., Rizvi, S. A. H., ... Lu, L. (2020). Evaluating the repellent effect of four botanicals against two Bactrocera species on mangoes. PeerJ, 8, e8537. https://doi.org/10.7717/peerj.8537.

Jin, T., Zeng, L., Lin, Y. Y., Lu, Y. Y., \& Liang, G. W. (2011). Insecticide resistance of the oriental fruit fly, Bactrocera dorsalis(Hendel) (Diptera: Tephritidae), in main land China. Pest Management Science, 67, 370-376 Goggle scholar.

Khan, M., Hossain, M. A., \& Islam, M. S. (2007). Effects of neem leaf dust and a commercial formulation of a neem compound on the longevity, fecundity and ovarian development of the melon fly, Bactrocera cucurbitae (Coquillett) and the oriental fruit fly, Bactrocera dorsalis (Hendel) (Diptera: Tephritidae). Pakistan Journal of Biological Science, 10(20), 3656-3661 Goggle scholar.

Lengai, G. M. W., Muthomi, J. W., \& Mbega, E. R. (2020). Phytochemical activity and role of botanical pesticides in pest management for sustainable agricultural crop production. Scientific African, 7, e00239. https://doi.org/10.1 016/j.sciaf.2019.e00239.

Mau, R. F. L., Jang, E. B., \& Vargas, R. I. (2007). The Hawaii fruit fly area-wide fruit fly pestmanagement programme: influence of partnershipand a good education programme. In M. J. B. Vreysen, A. S. Robinson, \& J. Hendrichs (Eds. ), Area-wide Control of Insect Pests: FromResearch to Field Implementation, (pp. 671-683). Springer Goggle scholar.

Mengesha, S., Abate, D., Adamu, C., Zewde, A., \& Addis, Y. (2019). Value chain analysis of fruits: The case of mango and avocado producing smallholder farmers in Gurage Zone, Ethiopia. Journal of Development and Agricultural Economics, 11(5), 102-109 Goggle scholar.

Mordue-Luntz, A. J., \& Nisbet, A. J. (2000). Azadirachtin from the neem tree Azadirachta indica its action against insect. Annal Society of Entomology Brasil, 29, 615-632 Goggle scholar.

Ofuya, T., Okoye, B., \& Olola, A. (1992). Efficacy of a crude extract from seeds of Monodora myristica (Gaertn.) Dunal as surface protectant againstCallosobruchus maculatus (F.) attacking legume seeds in storage. Journal of Plant Diseases amp; Protection, 99(5), 528-532

Oloke, J. O., Kolawole, D. O., \& Erhun, W. O. (1998). The antibacterial and antifungal activities of certain components of Aframomum meleguetea fruits. Fitoterapia, 59(5), 384-388. 
Radha, R., \& Susheela, P. (2014). Studies on the life history and ovipositional preference of Callosobruchus maculatus reared on different pulses. Research Journal of Animal, Veterinary and Fishery Sciences, 2(6), 1-5 Goggle scholar.

Rahmani, A. H., Al Shabrmi, F. M., \& Aly, S. M. (2014). Active ingredients of ginger as potential candidates in the prevention and treatment of diseases via modulation of biological activities. International Journal of Physiology, Pathophysiology and Pharmacology, 6(2), 125-136.

Regnault-Roger, C., \& Hamrouni, A. (1995). Fumigant toxic activity reproductive inhibition induced by monoterpenes on Acanthoscelides obtectus (Say), a bruchid of kidney bean. Journal of Stored Products Research, 31, 291-299 Cross ref. Goggle scholar.

Rehman, J., Jilani, G., Khan, M. A., Masih, R., \& Kanvil, S. (2009). Repellent and oviposition response and fecundity of peach fruit fly (Diptera: Tephritidae). Pakistan Journal of Zoology, 38, 131-135 Goggle scholar.

Roessler, Y. (1989). Insecticidal bait and cover sprays. World Crop Pests, 3, 329-337 Goggle scholar.

Saul, S. H., Tsuda, D., \& Wong, T. T. (1983). Laboratory and field trials of soil applications of methoprene and other insecticides for control of the Mediterranean fruit fly (Diptera: Tephritidae). Journal of Economic Entomology, 76(1), 174-177 Goggle scholar.

Scott, I. M., Jensen, H., Nicol, R., Lesage, L., Bradbury, R., Sánchez-Vindas, P.. ... Philogène, B. J. R. (2004). Efficacy of Piper (Piperaceae) Extracts for Control of Common Home and Garden Insect Pests. Journal of Economic Entomology, 97(4), 1390-1403. https://doi.org/10.1093/jee/97.4.1390.

Shivendra, S., \& Singh, R. P. (1998). Neem (Azadirachta indica) seed kernel extracts and azadirachtin as oviposition deterrents against the melon fly (Bactrocera cucurbitae) and the oriental fruit fly (Bactrocera dorsalis). Phytoparasitica, 26, 191-197 Goggle scholar.

Siddiqi, A. R., Jilani, G., Rehman, J. U., \& Kanvil, S. (2006). Effect of turmeric extracts on settling response and fecundity of peach fruit fly (Diptera: Tephritidae). Pakistan Journal of Zoology, 38, 131-135 Goggle scholar.

Solangi, B. K., Sultana, R., Wagan, M. S., \& Ahmed, N. (2011). Repellent action of botanical pesticides against fruit fly, Bactrocera zonata Saunders in laboratory. Pakistan Journal of Entomology, 26(1), 41-45 Karachi, Goggle scholar.

Stephens, A. E. A., Kriticos, D. J., \& Leriche, A. (2007). The current and future potential geographical distribution of the oriental fruit fly, Bactrocera dorsalis (Diptera:Tephritidae). Bulletin of Entomological Research, 97, 369-378 Goggle scholar.

Tjendraputra, E., Tran, V. H., Liu-Brennan, D., Roufogalis, B. D., \& Duke, C. C. (2001). Effect of ginger constituents and synthetic analogues on cyclooxygenase-2 enzyme in intact cells. Bioorganic Chemistry, 29(3), 156-163 Google scholar.

Ugwu, J. A. (2020). Bioassays of four different botanicals against Mediterranean fruit fly, Ceratitis capitata (Diptera: Tephritidae) larvae under laboratory conditions. In Proceedings of 38th Annual Conference of the Horticultural Society of Nigeria (Hortson) Nsukka- 2020, (pp. 145-151).

Ugwu, J. A., \& Nwaokolo, V. M. (2020). Biocidal activity of selected botanicals and Beauveria Bassiana on oriental fruit fly, Bactrocera Dorsalis (Diptera; Tephritidae). Journal of Research in Forestry, Wildlife \& Environment, 12(1), 5361 https://www.ajol.info/index.php/jrfwe/article/view/194330.

Ugwu, J. A., Ojo, M. O., Aderolu, I. A., \& Aderemi, F. O. (2014). Studies on the Efficacy of Azadirachta indica A. Juss, Piper guineense (Schum \& Thonn) seed extracts and Chlorpyrifos on Insect Pests of Abelmoschus esculentus $(L)$ Moench in Ibadan South West Nigeria. International Journal of Applied Research and Technology, 3(2), 25-31 Google scholar.

Ukeh, D. A., Birkett, M. A., Pickett, J. A., Bowman, A. S., \& Luntz, A. J. (2009). Repellent activity of alligator pepper, Aframomum melegueta, and ginger, Zingiber officinale, against the maize weevil, Sitophilus zeamais. Phytochemistry., 70(6), 751-758. https://doi.org/10.1016/j.phytochem.2009.03.012.

Vargas, R. I., Leblanc, L., Piñero, J. C., \& Hoffman, K. (2014). Male annihilation, past, present, andfuture. In T. Shelly, N. Epsky, E. B. Jang, J. Reyes-Flores, \& R. I. Vargas (Eds.), Trapping and theDetection, Control and Regulation of TephritidFruit Flies, (pp. 494-511). Springer Goggle scholar.

Vargas, R. I., Mau, R. F. L., Jang, E. B., Faust, R. M., \& Wong, L. (2008). The Hawail fruit fly area-widepest management program. In O. Koul, G. W. Cuperus, \& N. C. Elliott (Eds.), Area wide IPM Theory to Implementation, (pp. 300-325). CABI Books Goggle scholar.

Vargas, R. I., Peck, S. L., McQuate, G. T., Jackson, C. G., Stark, J. D., \& Armstrong, J. W. (2001). Potential for area-wide integrated management ofMediterranean fruit fly with a braconid parasitoidand a novel bait spray. Journal of Economic Entomology, 94, 817-825 Goggle scholar.

\section{Publisher's Note}

Springer Nature remains neutral with regard to jurisdictional claims in published maps and institutional affiliations.

\section{Submit your manuscript to a SpringerOpen ${ }^{\circ}$ journal and benefit from:}

- Convenient online submission

- Rigorous peer review

- Open access: articles freely available online

- High visibility within the field

- Retaining the copyright to your article

Submit your next manuscript at $\boldsymbol{\nabla}$ springeropen.com 